\section{artelogie}

\section{Artelogie}

Recherche sur les arts, le patrimoine et la littérature de l'Amérique latine

$15 \mid 2020$

Latin American networks: Synchronicities, Contacts and Divergences.

\title{
José Gómez Sicre and his Impact on the OAS' Visual Arts Unit: For an International Latin American Art
}

José Gómez Sicre and his Impact on the OAS'Visual Arts Unit: For an International Latin American Art ${ }^{2}$

Ivonne Pini and María Clara Bernal

Translator. Jane Brodie

\section{(2) OpenEdition}

Journals

Electronic version

URL: http://journals.openedition.org/artelogie/4757

DOI: 10.4000 /artelogie.4757

ISSN: 2115-6395

Publisher

Association ESCAL

\section{Electronic reference}

Ivonne Pini and María Clara Bernal, « José Gómez Sicre and his Impact on the OAS'Visual Arts Unit: For an International Latin American Art », Artelogie [Online], 15 | 2020, Online since 29 April 2020, connection on 04 August 2020. URL : http://journals.openedition.org/artelogie/4757

This text was automatically generated on 4 August 2020

Association ESCAL 


\title{
José Gómez Sicre and his Impact on the OAS' Visual Arts Unit: For an International Latin American Art ${ }^{1}$
}

\author{
José Gómez Sicre and his Impact on the OAS' Visual Arts Unit: For an \\ International Latin American Art ${ }^{2}$
}

Ivonne Pini and María Clara Bernal

Translation: Jane Brodie

1 In this text, we will explore how Cuban cultural manager José Gómez Sicre contributed to the consolidation of policies on Latin American art from his post as director of the Visual Arts Unit of the OAS. To that end, we surveyed and analyzed his personal archive, housed in the Nettie Lee Benson Latin American Collection of the University of Texas at Austin, to which we had access thanks to the Getty Foundation's Connecting Art Histories grant.

2 At the close of the nineteen-forties, the Organization of American States (OAS) proposed, in a tacit but resounding manner, a set of parameters with which to promote Latin American art in the international sphere. Acting through its Visual Arts Unit, the OAS supported exhibitions that, along with the Bulletin of Visual Arts, aimed to contribute to the formation of a specific model, one that, in the eyes of José Gómez Sicre and others, would ensure the insertion of art produced in Latin America in the global circuits of modern art.

3 The postwar period-the one addressed here-witnessed a shift in relations between the United States and Latin America. In the context of the Cold War and after the triumph of the Cuban Revolution, the United States launched new programs to counter what it deemed the danger of the spread of the Cuban model. We are interested here in how those changes restructured the dynamic of the art world and, specifically, in how they affected the model advocated by the OAS' Visual Arts Unit.

4 The OAS' Visual Arts Unit cannot be analyzed without also looking at the policies advocated by MoMA. Before and during the war, in the framework of President 
Roosevelt's Good Neighbor policy (Roosevelt was in office from 1933 to 1945), MoMA purchased works from Latin American countries as part of a diplomatic strategy to gain allies. The trips North Americans took to Latin America to formalize those purchases were also an excuse to learn about what was happening in the region politically and socially, and to look for allies there. One of MoMA's consultants in the forties was Lincoln Kirstein. ${ }^{3}$ He traveled to a number of countries in Latin America, and while there he would send the State Department reports on what he found.

5 In the nineteen-forties, the executive power of the United States created the Office of the Coordinator of Inter-American Affairs to stimulate cultural and commercial exchange with Latin America. Due to his experience with Latin America and his contacts there through family business interests, Nelson Rockefeller was named its director. The new entity had considerable impact on the art field through its Art Department which, using its relationship with MoMA as an instrument, held exhibitions. The Museum promised to coordinate the organization of the exhibitions and their tours around the United States and Latin America. One of the core motivations for strengthening relations between the United States and Latin America was cultural collaboration as a means to isolate first fascist-leaning and later totalitarian-leaning tendencies in different countries. MoMA's approach to Latin America was tied to the agenda of the Inter-American Fund. In later decades as well, those shared interests were evident. In the late fifties, MoMA increased its acquisitions of Latin American works in an attempt to counter the implications of the triumph of the Cuban Revolution. In the sixties, under President Kennedy, the Alliance for Progress reinforced ties between the United States and the countries to the south not only in the economic and social spheres, but also in the realm of culture.

6 Relevant in this context is the relationship between José Gómez Sicre and Alfred H. Barr $\mathrm{Jr}^{4}$ the director of MoMA at the time. The correspondence between them, housed in the aforementioned archive, begins in 1942, but their relationship predates it. They met when Barr visited Cuba, where he was hosted by María Luisa Gómez Mena, a Cuban sugar magnate and modern art patron.

7 The very first letter, dated August 1942, attests to an affinity between Barr and Gómez Sicre that would allow them to work together on cultural policies during the Cold War. The letter reads: "Dear Pepe: You know that I cannot possibly repay you for all the time and the thought which you gave us during our Cuban visit. You are a very remarkable man, for you combine intelligence and knowledge with extraordinary fairness and disinterested appreciation of a great variety of artists and of art." ${ }^{5}$ At the end of the letter, Barr asks Gómez Sicre to keep him informed of what was happening in Cuban art. He expresses interest in using his connections at MoMA to internationalize Cuban art and Latin American art in general.

8 The correspondence sheds light not only on how their relationship was built, but also on the policies and expectations it entailed. In 1943, Barr asked Gómez Sicre to help him get the support of Cuban President Gerardo Machado for an exhibition of Cuban art in the United States. That same year, Gómez Sicre had organized the "Exposición de Pintura y Escultura Moderna Cubana" at the Institución Hispano Cubana de Cultura in Havana.

9 Barr's request of Gómez Sicre would lead to the show "Modern Cuban Painters," which opened at MoMA in March 1944. While it did not have the formal support of the Cuban government, it was, according to the MoMA press release, sponsored by María Luisa 
Gómez Mena; ${ }^{6}$ Alfred Barr, as the Museum's Advisory Director, was responsible for selecting the works to exhibit. At the exhibition, Gómez Sicre's book Pintura Cubana de Hoy, also funded by Gómez Mena, was for sale. The show toured the United States for two years. ${ }^{7}$ News of it reached Cuba, and it was reviewed in newspapers like the Gaceta del Caribe under headlines like "Cuban Colors in New York." The tone of that article, at

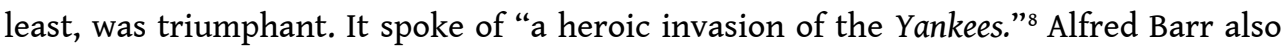
sent a letter to the editor of the Gaceta del Caribe in which he spoke of the success enjoyed by Cuban painting in New York. ${ }^{9}$

The correspondence between Gómez Sicre and Barr also speaks of a show of watercolors and drawings entitled Watercolor and Drawing by Six Cuban Painters, which toured with the support of MoMA. That exhibition, unlike the earlier one, was exhibited at less prominent locations in the United States. In recognition of his work on the two shows, the MoMA Board of Directors gave Gómez Sicre an honorary ten-year membership to the Museum.

\section{Latin American Art in the Context of International Modern Art}

11 Gómez Sicre arrived in New York with the support of Barr who, in the letters they exchanged, advised him to apply for a scholarship to get a master's degree in fine arts from New York University. What mattered, Barr explained, was not going to classes but finding a way to come to New York and make contacts. But soon after Gómez Sicre got his funding, something unexpected happened: Barr's tenure as the director of MoMA came to an end. He did stay on as an adviser to the new director, René d'Harnoncourt, which meant the exhibitions planned during his tenure took place. Notwithstanding, the fact that Barr was no longer the director of MoMA was an obstacle to the relationship between the Cuban and the Museum. The fact that the publication of Gómez Sicre's book Cuban Painting Today (1944) was funded by María Luisa Gómez Mena instead of by MoMA attests to the lesser interest on the part of the Museum's new authorities in supporting Gómez Sicre. ${ }^{10}$

Though Gómez Sicre's relationship with MoMA yielded no additional fruit, Barr's strategy did: Gómez Sicre was able to establish the ties necessary to move to Washington and begin the career that would make him the influential figure he became. According to an autobiographical text in the Neetie Lee Benson Collection, Gómez Sicre was responsible for establishing a program of art exhibitions at the PanAmerican Union (1946), which would be turned into the OAS in two years' time. In 1949, Gómez Sicre was named the head of the institution's Visual Arts Unit, and in 1976 the director of the Museo de Arte Contemporáne de América Latina (Museum of Latin American Contemporary Art) (he retired from that post in 1983). Gómez Sicre was key to furthering a certain model of Latin American art. To that end, he built a collection of the region's art that informed its international profile for thirty-six years, a model that promoted certain individuals over others.

Our study of the archive showed that Gómez Sicre's post at the OAS and his relationship to Alfred Barr and MoMA affected not only the conception of Latin American art in the United States but also in a number of art collections and institutions in the region itself. Thanks in part to his many trips to Latin America, Gómez Sicre became an 
influential personality who advocated a model that attempted to incorporate Latin America into the international modern art model while also rendering it exportable and acceptable to the international market. He enacted those ideas from his post at the OAS and through regional initiatives like the Salón Esso, ${ }^{11}$ which he organized and in which he acted as a juror.

Gómez Sicre was expressly against local schools and in favor of modern art, a term he relativized. His conception of the modern was clearly influenced by Alfred Barr. ${ }^{12}$ Gómez Sicre believed that Latin America should make use of an international artistic language like the one prevalent in the United States, and that its artists should pursue a style compatible with the rest of the hemisphere. He held that the United States should be the engine behind the construction of the international language: "As the richest and most developed country, it should be the primary driver and the natural center of culture to the benefit of all the countries in the continent" (GÓMEZ SICRE, 1959: p. 22-23).

15 His argument makes clear his belief that forming part of Western culture, doing away with regionalisms and-of course-with any hint of political narrative, as well as embracing an international language was the means to legitimize Latin American art. Westernism and internationalism were, then, the cornerstones of the art he advocated.

The modernism Gómez Sicre championed did recognize the potential value of what he called the "Latin American accent" in modern art. If, he argued, Latin Americans used to go to Europe to learn about art, they could now-whether they lived in Europe or in the United States-help shape the fate of international modernism. In other words, they should go from being students and apprentices to being decisive players in the configuration of what they considered their own form of expression linked to international modern art.

Exhibitions like 32 Artistas de las Américas: Exposición realizada por la Unión Panamericana attempted to establish a new canon of Latin American art, questioning muralism and upholding abstraction and expressionism. Held at the Museo Nacional de Bogotá in 1949, the show was part of the agenda of cultural activities organized by the Visual Arts Unit of the Pan-American Union (GÓMEZ SICRE, 1959: p.22-23). The works featured belonged to collections in the United States-MoMA in more than half the cases. The introduction underscored the exhibition's central aim, namely to demonstrate America as ideal site for artistic creation in a free state:

Please take this set of works as an anthology of the most independent facets of the artistic sentiment of the Americas. Like all anthologies, it is inevitably susceptible to oversights. Any controversy it incites will be a sign that it has achieved its immanent and final objective: to stimulate thought, whether in favor or against. That is what will kindle new lights and consolidate unshakeable concepts.

This exhibition does not seek to incite needless controversy, but rather to manifest that in the Americas man can let his spirit explore all categories and dimensions of creation-which is how it should be in a continent committed to the pursuit of freedom. If that conception took root, that would be sufficient reward for this exhibition's mission (GÓMEZ SICRE, 1949: n.p.).

While it was ingenuous to believe that the exhibition could impose a homogenizing model on modern art of the Americas, it did have a major impact on what was 
increasingly accepted in the region as modern art. Furthermore, it paved the way for the OAS, through its Visual Arts Unit, to play a leading role in defining what was seen as forward-looking art from Latin American.

In the catalogue to another show of Latin American art, this one at the Dallas Museum of Fine Arts in 1959, Gómez Sicre insists on a change in paradigm. He describes what viewers will find: it will not, he warns, be picturesque scenes, but rather works by modern artist from ten countries using new forms of expression in their explorations. "The creative talents of Latin America have acquired a world vision which enables them to express national themes in subtle accents, rather than by raw, literal reproductions" (GÓMEZ SICRE, 1959: n.p.) Almost all the artists selected for the show, who are presented individually after the general introduction cited above, subscribed to geometric abstraction. The brief biographies in the catalogue always refer to their studies outside their countries of origin.

Though Gómez Sicre did not support Mexican muralism, and wrote off interest in it as interest in "imported works acquired in a tourist spirit," he does recognize it as the most important antecedent to the internationalism that he pursued for Latin American art. In his view, three artists-Rivera, Orozco, and Siqueiros-were able, in the midst of the Great Depression in the United States, to go beyond borders. They were warmly welcomed in the artistic centers of their neighbor to the north: "We could say that that was the first time a Latin American nation exported a prestigious work to North American centers." ${ }^{13}$

\section{Gómez Sicre chooses central figures to signal what Latin American art should be like}

In the draft of his contribution to the issue of Vanidades magazine published in his honor in 1976, Gómez Sicre wrote:, "[...] we have a distinctive accent in art, just as we have a distinctive accent in Spanish." He then goes on to list artists that, in his view, represent "the Latin American accent": Orozco, Siqueiros, Tamayo, and Cuevas in Mexico; Figari and Torres García in Uruguay; Carlos Mérida in Mexico-Guatemala; Amelia Peláez and Cundo Bermúdez in Cuba; and Alejandro Obregón in Colombia. He didn't mention anyone in particular in Argentina because, he said, "there were too many to name." ${ }^{14}$

That concept of the "Latin American accent" was particularly dangerous insofar as it epitomized a number of increasingly accepted affirmations that characterized the region's art as uniform. There was a risk, then, of replacing one set of stereotypes with another.

Gómez Sicre advocated for a number of figures in modern art, but he championed none more than Mexican artist José Luis Cuevas. Cuevas is mentioned a great deal in Gómez Sicre's writings, speeches, and interviews. The young Cuevas's criticism of "chabacano Mexican nationalism" made him a figure central to challenging the vast painted surfaces and the heroism so characteristic of the work of the three great Mexican muralists. With its small drawings of distressed characters of unidentifiable nationality, Cuevas's work seemed akin to the Existential philosophy so popular in the postwar era, hence his importance to Gómez Sicre's criticism of muralism. 

Gómez Sicre wrote for $\mathrm{El}$ Nacional newspaper, he attempts to lay out for young artists some of the things he considers key to his vision of Latin American art: a) Discipline: art is a demanding craft, and you must train in technique every day. ${ }^{19} \mathrm{~b}$ ) Do not pursue originality as the only possible aim. c) "Deep reverence of nature as point of departure." d) Avoid any nationalist intent. As pointed out above, for Gómez Sicre it was essential that an art that would be called Latin American have a hefty dose of internationalism. To that end, he often cited José Luis Cuevas as a counterexample of 
Mexican muralism and its outgrowths, and of indigenism-embodied in Guayasamínwhich he saw as the degeneration of what is called Latin American art. The final point on his list (point e) is self-criticism. ${ }^{20}$

\section{The Art-Ideology Relationship} a state of freedom. For him, that freedom was not about producing art without external pressure or coercion, but about not working under leftist regimes. In the undated manuscript to a catalogue text he titled "Para la exposición en Berlín," Gómez Sicre states: "The works gathered here have a common denominator: they were all created in a state of freedom, and they all bear witness to what man can achieve when not held back by religious doctrines or political ideologies." ${ }^{21}$ His other writings, along with his manifest preferences for certain artists and schools, make it clear which "political ideologies" he had in mind: anything in any way connected to communism was, in his view, unacceptable. “[...] Like almost all Cubans, I was a follower of Fidel on January 1, 1959. ${ }^{22}$ I intended to go home and serve my country. In fact, I offered to but they were not interested. After Castro declared himself a Communist, I began to openly oppose the Revolution." ${ }^{23}$ That is significant because, as was to be expected, Gómez Sicre's relationship with Cuban art was affected by the Revolution. The artists who left the island immediately gained his support. He wrote about their work and even gave them solo shows in the OAS' galleries-not, in many cases, because of their skill as artists but because of the political beliefs that led them to leave the island. Similarly, the artists who chose to stay in Cuba after Castro declared himself a Communist were, with just a handful of exceptions, the object of his harsh criticism.

Regarding the accusation that he had written off leftist artists, Gómez Sicre explained, "I didn't leave anyone out [of the Esso salon] because of their politics, as long as they were not Siqueiros-style Communists." ${ }^{24}$ That denial in his answer is striking because it makes more evidente the weight that his ideology has on his choices. In the same interview, he denies his ties to the CIA, but admits having played a role in the Cold War, especially in Cuba. "I have never been an ally of banana-republic right-wingers or fascists. In politics, I have always admired anticommunist liberals like Betancourt in Venezuela and Arévalo in Guatemala. I am and have always been anti-Franco and antiBatista."25

Despite those ambiguous statements, it is clear that artists who, in one way or another, had shown leftist inclinations were not considered by Gómez Sicre; those who were selected were influenced by "internationalism." But that wasn't all. At stake as well was a series of requirements that were not intrinsic to the artist's work. Cuban artist Wifredo Lam, for instance, met all the requirements to be an "international Latin American.” Notwithstanding, Gómez Sicre's aversion to him was patent. 
When he is asked, "What do you think of Lam as a painter?" Gómez Sicre replies, "He's not bad. He did some good work, mostly in the forties. But he is by no means the genius that Lydia Cabrera and Lam himself make him out to be. Since the forties, he has repeated himself a lot. Personally, he is detestable. He was very much the Trotskyite and the surrealist until 59, when he reinvented himself as a pro-Soviet Leninist. You know that Lam doesn't talk like a Cuban? That's what Picasso said." 26

\section{By Way of an Epilogue: Gómez Sicre's Reception in the Art Milieu} aims he pursued. He was, by the end of his career, worn out by his run-ins with bureaucrats and peers, and by his campaign to change the image of Latin American art and to advocate some of its artists. All of that was at stake, he believed, in his role as an art critic.

In an interview held after he left the institution, Gómez Sicre, at the request of Alejandro Anreus, provides an account of his advent at the OAS. In an attempt to show how important he was to the OAS and to demonstrate the changes he ushered in there, Gómez Sicre tells Anreus that, "When I arrived it was called the Pan-American Union and there were a few parrots on the grounds. I had to struggle against the bureaucracy until my departure in 1983." ${ }^{27}$ Gómez Sicre does not provide an accurate sense of his impact on the OAS. In some cases-like when he claims to have "discovered artists"-he overestimates it, and in others-specifically regarding his influence on public and private art collections in the United States and Latin America-he underestimates it.

The press clippings, transcriptions of speeches, catalogue texts, and letters from artists and critics found in the archive speak often of how influential Gómez Sicre was. The exhibitions he organized at the Pan-American Union/OAS were, in many cases, artists' first shows in North America (Alejandro Obregón) or even outside their home countries (Fernando Botero, Gómez Sicre assures). The contents of the archive make frequent reference to him as the one responsible for "discovering artists" which, to him, meant introducing them to the international scene. That was, in part, the source of his power. As the center of art was migrating from Paris to New York, the opportunity to show work in the United States with the support of a protégé of Alfred Barr was not to be shunned.

The OAS exercised influence not only on the image of Latin American art in the United States but also in Latin America itself. According to Gómez Sicre, "Not only was the OAS' gallery in Washington extremely active, but it also advocated abroad the most renowned artists who passed through it. The São Paulo Biennial, in Brazil, was a befitting venue from which to expand the nascent prestige of those artists who, because of their talent, had triumphed in the Washington gallery. Indeed, the OAS served to provide a wide range of artists with access to an important venue in which many Latin American countries did not participate because they did not accept their modern artists. It was through the OAS that different artists entered each edition of the Biennial after having had their first shows in the OAS' gallery." ${ }^{28}$

The texts in Gómez Sicre's archive evidence his constant concern with how Latin American art was being received outside the region. He wanted to bring an end to the 
image of traditional and indigenous art. In one of the many accounts of his life found in the archive, he states that the only Latin American artists shown regularly at the New York Museum of Modern Art were Wifredo Lam and Roberto Matta. He believed it was because they were seen as part of the School of Paris. He complains that since 1944, the year when the exhibition of Cuban art was held at MoMA, "the museum has not shown a single group of works that represents Latin America or that recognizes its contribution to universal art." ${ }^{29}$

In a handwritten text entitled "Arte Latinoamericano 1954-1983" written during the final phase of his public activity, Gómez Sicre takes stock of the history of Latin American art in the United States, identifying three stages: the initial support of muralism; the importance of Brazil through Cándido Portinari in 1939; and the rise of Haitian art. In his judgement, all three were fleeting moments governed by external circumstance. He also assesses his own work. He argues that his impact was wide, not limited to just a few countries. Unlike the earlier three instances cited, his work would, he believed, leave a lasting legacy.

Gómez Sicre's influence on the development and spread of Latin American art is a subject of controversy for the art world both in his time and later. In an article published in El Universal in January 1983, Marta Traba wrote that after a long career the time had come for Gómez Sicre to step down from his post at the OAS. She argued that, despite claims to the contrary, the Museo de Arte Moderno de Latinoamérica was not a priority of the OAS, as was evident in its meager budget and shabby condition. She recognized Gómez Sicre's important role as the creator of the museum and the collection, which in her view was erratic, but she argued that someone "more knowledgeable" was needed at the helm of the museum.

A few years later, on the occasion of the tribute paid to him at the Museum of Contemporary Art in Washington (1989), Juan Acha wrote to Gómez Sicre: "I am convinced of your professional merits as an advocate of Latin American visual arts internationally, as well as of your critical knowledge of the evolution and the greatest exponents of the region's production." Remembering when they met, he states, "We saw you as an example. Without setting out to, you influenced the sensibility and the intellect of those of us working or beginning to work as art critics ... in any case, you freed our arts from provincialisms." ${ }^{30}$

In the article "Pequeño homenaje a José Gómez Sicre" published by Peruvian painter Fernando de Syszlo in Lima after Gómez Sicre's death, he writes: "Before Gómez Sicre, there was, as I see it, Argentine and Mexican art, Peruvian and Venezuelan art. He was the one who saw that all of those expressions, albeit in a hidden or ineffable fashion, were bound by common denominators [...] He invented not only the term Latin American art, but also the idea that it holds." ${ }^{31}$

Raquel Tibol and Shifra Goldman, on the other hand, are highly critical. They accuse him of having brought U.S. corporations into Latin American art, specifically through the Salón Esso. Tibol argues that the Organization of American States attempted to impose abstract art to the detriment of the figurative movements around the continent -and Gómez Sicre played a central role in that project, enacting a cultural policy directed by the State Department. She condemns North American cultural imperialism that sought to impose a single artistic tendency and that led to neglect of important strains of Mexican art. 


\section{NOTES}

1. When Goméz Sicre was named director of the Visual Arts Unit, the organization was known as the Pan-American Union. The name was changed to the Organization of American States (OAS) in 1948. We use that name in this text, regardless of date.

2. When Goméz Sicre was named director of the Visual Arts Unit, the organization was known as the Pan-American Union. The name was changed to the Organization of American States (OAS) in 1948. We use that name in this text, regardless of date.

3. Kirstein (1907-1996) was a central figure in the New York cultural scene due both to his work at MoMA and his role in the founding of the New York City Ballet.

4. Alfred Barr was the director of the New York Museum of Modern Art from 1929 until 1943, when he was named adviser to the director and, later, director of collections.

5. Letter from Alfred Barr to José Gómez Sicre dated August 16, 1942. Unpublished material in the José Gómez Sicre Papers, Nettie Lee Benson Latin American Collection Archive, University of Texas at Austin, box 7, folder 2 .

6. In the undated press release entitled "Museum of Modern Art Announces Exhibition of Modern Cuban Painters" announcing the opening of an exhibition that would feature work by Ponce de León, Amelia Peláez, Carlos Enríquez, Mariano, Mario Carreño, and Cundo Bermúdez. 
7. From October 1944 to May 1945, the show traveled to Chicago, Utah, Washington, and Minneapolis. Information in a letter dated September 22, 1944. Unpublished material in the José Gómez Sicre Papers, Archive Nettie Lee Benson Latin American Collection, University of Texas at Austin, box 7, folder 2. Letters to Gómez Sicre from MoMA dated 1946-by which time he was working at the Pan-American Union-indicate that the show was handled according to the norms of the time: a number of works were sold not only to some of the institutions that housed it on the tour, but also to MoMA beforehand, and the money was divided between Gómez Sicre and the participating artists.

8. "Colores cubanos en Nueva York" at Gaceta del Caribe, Havana, May 1944.

9. Letter from Alfred Barr to the editorial board of Gaceta del Caribe, dated July 18, 1944. Unpublished material in the José Gómez Sicre Papers, Archive Nettie Lee Benson Latin American Collection, University of Texas at Austin, box 7, folder 2. We find this letter particularly interesting for a number of reasons: 1) it mentions problems that a foreigner would have trouble detecting during a short visit like Barr's to Cuba; 2) it is written in fluent Spanish, which is startling since most of the letters the North American critic wrote to Gómez Sicre were in English; 3) Gómez Sicre and his ally, María Luisa Gómez Mena, are mentioned as benefactors and as opponents to Wilfredo Lam's project (Gómez Sicre and Lam had serious ideological differences); 4) it is not signed by Barr, though his name appears at the bottom. For all of those reasons, one might think that Gómez Sicre was directly involved in writing the letter in order to validate his position.

10. The correspondence makes it clear that Gómez Sicre had to seek María Luisa Gómez Mena's support since MoMA had retracted its early support because it could not use more than a certain amount of paper.

11. The Esso Salons of Young Artists (1965) were held in over twelve Latin American cities. The award-winning artists in each one then participated in a competition in Washington at which two winners and six mentions were named. Gómez Sicre formed part of all the international juries-presided over by Thomas Messer, director of the Guggenheim Museum-except for the one in Mexico.

12. The question of how much Clement Greenberg's stance at this time influenced Gómez Sicre's conception of modernism merits further study.

13. Text from the "Artes Plásticas en Latinoamérica 1954-1983" archive.

14. Participants in the show included Luis Barragán, J. Antonio Fernández Muro, Sara Grilo, Emilio Pettoruti, and Rogelio Polesello.

15. No date or place of publication, but there is a note in which Obregón thanks him for the text for an exhibition catalogue.

16. Collection, Universidad of Texas at Austin (n. d., n. p.). This text was presumably written for an exhibition catalogue.

17. Interview with Alejandro Anreus (n.d.). Unpublished material in the José Gómez Sicre Papers, Nettie Lee Benson Latin American Collection Archive, University of Texas at Austin, Box 1, folder 4.

18. Interview with Alejandro Anreus (n.d.). Unpublished material in the José Gómez Sicre Papers, Nettie Lee Benson Latin American Collection Archive, University of Texas at Austin, Box 1, folder 4.

19. In the aforementioned interview with Vanidades, he stated that conceptual art and happenings were "nonsense" and he was happy Latin American artists had not been infected with them. 
20. Unpublished material in the José Gómez Sicre Papers, Nettie Lee Benson Latin American Collection Archive, University of Texas at Austin. In July 1948, the Taller Libre de Arte was opened in Caracas-a brainchild of, among others, Gómez Sicre. The studio set out to be a space where young artists could work, gather, and hold exhibitions. In Marta Traba's view, though, the Taller Libre de Arte "was more tied to the past than to the future". Marta Traba, Mirar en América, Caracas, Fundación Ayacucho, 2005, p. 268.

21. Unpublished material in the José Gómez Sicre Papers, Nettie Lee Benson Latin American Collection Archive, University of Texas at Austin.

22. The day the Cuban Revolution declared victory over Fulgencio Batista y Zaldívar.

23. Interview with Alejandro Anreus (n. d.). Unpublished material in the José Gómez Sicre Papers, Nettie Lee Benson Latin American Collection Archive, University of Texas at Austin, Box 1. Folder 4.

24. Interview with Alejandro Anreus (n. d.). Unpublished material in the José Gómez Sicre Papers, Nettie Lee Benson Latin American Collection Archive, University of Texas at Austin, Box 1. Folder 4.

25. Interview with Alejandro Anreus (n. d.). Unpublished material in the José Gómez Sicre Papers, Nettie Lee Benson Latin American Collection Archive, University of Texas at Austin, Box 1. Folder $4 \ldots$

26. Interview with Alejandro Anreus (n. d.). Unpublished material in the José Gómez Sicre Papers, Nettie Lee Benson Latin American Collection Archive, University of Texas at Austin, Box 1. Folder 4.

27. Interview with Alejandro Anreus (n. d.). Unpublished material in the José Gómez Sicre Papers, Nettie Lee Benson Latin American Collection Archive, University of Texas at Austin, Box 1. Folder 4 .

28. Text by José Gómez Sicre assessing his work in the José Gómez Sicre Papers, Nettie Lee Benson Latin American Collection Archive, University of Texas at Austin. Folder 3.

29. Text by José Gómez Sicre assessing his work in the José Gómez Sicre Papers, Nettie Lee Benson Latin American Collection Archive, University of Texas at Austin. Folder 3.

30. Unpublished manuscript of the speech Juan Acha gave honoring Gómez Sicre, Museum of Contemporary Art in Washington, 1989, in the José Gómez Sicre Papers, Nettie Lee Benson Latin American Collection Archive, University of Texas at Austin. Folder 3.

31. OIGA magazine, July 30, 1991, p. 57.

\section{ABSTRACTS}

Starting at the end of World War II and with the onset of the Cold War, the Organization of American States' Visual Art Unit, under director José Gómez Sicre, advocated a specific model of Latin American art. Gómez Sicre's relationship with Alfred Barr, the director of the New York Museum of Modern Art and, through it, his influence on the museum's policies regarding Latin America art-that is, the decision to support a specific formula and what that formula should be -was pivotal. The model he championed centered on three aspects: internationalism, Western 
thought and anticommunism. That model entailed a harsh questioning of what were seen as local formulations at a distance from that central vision.

Depuis le début de la deuxième après-guerre et surtout avec le développement de la Guerre froide, le département des Arts visuels de l'OEA, sous la direction de José Gómez Sicre, a encouragé un modèle particulier d'art latino-américain. La relation entre José Gómez Sicre et Alfred Barr, le directeur du New York Museum of Modern Art, ainsi que les politiques promues par le MoMA de New York ont contribué à valider une formule artistique qui devrait être stimulée en Amérique latine. Celle-ci consistait à mettre en exergue trois aspects considérés comme centraux : l'internationalisme, l'occident et sur le plan politique l'anticommunisme. En parallèle, les approches locales qui éloignaient l'art du modèle centralement promu furent fortement questionnées.

\section{INDEX}

Mots-clés: Art latino-américain, guerre froid, OEA (Organisation des États américains), MoMA, José Gómez Sicre, Alfred Barr, l'internationalisme, anti-comunisme

Keywords: Latin American art, the Cold War, OAS, MoMA, José Gómez Sicre, Alfred Barr, internationalism, anticommunism

\section{AUTHORS}

\section{IVONNE PINI}

Ivonne Pini is a distinguished full professor at the Universidad Nacional de Colombia (Universidad de los Andes). She also teaches in the Art History Department of the Universidad de los Andes. She is the executive editor of Art Nexus and a member of the editorial committee of $\mathrm{H}_{-}$ ART. Revista de historia, teoría y crítica de arte, the publication of the Universidad de los Andes Art History Department. She has written a number of books and essays, and contributed chapters to books on Latin American art.

\section{MARÍA CLARA BERNAL}

María Clara Bernal Ph.D is an associate professor in the Universidad de los Andes Art History Department (Bogotá) and director of that university's post-graduate Arts and Humanity Program. She is the editor of H-Art: Historia, Teoría y Crítica de Arte and the president of the Comité Colombiano de Historiadores del Arte. 